\title{
Immigration status of foreign citizens as a subject of administrative and legal regulation in host countries (rather-legal analysis)
}

\author{
Zinaida Stolyarova ${ }^{1}$ and Albina Uskova ${ }^{2, *}$ \\ ${ }^{1}$ Academy of Management of the Ministry of Internal Affairs of Russia, 8, Zoe and Alexander \\ Kosmodemyanskikh street, 125993, Moscow, Russia \\ ${ }^{2}$ Moscow Region State University, 10A, Radio str., 105005, Moscow, Russia,
}

\begin{abstract}
One of the topical issues that refer to legal status of foreign residents who live in host countries is the change of a purpose of entering this country, which entails the change of their immigration status. The paper deals with the issues of legal regulation of immigration status of foreign citizens, analyzes the experience of both foreign countries and the Russian Federation in resolving the issue of changing the immigration status without leaving a country. The authors have made some proposals on improving the system of legal regulation in the Russian Federation, which would help efficiently solve the problem under analysis.
\end{abstract}

\section{Introduction}

To confirm its social, democratic and legal spirit, The Russian Federation should be concerned of the complete enforcement of not only its own citizens' rights, freedoms and legal interests, but also the same rights, freedoms and legal interests of foreign citizens and stateless persons who legally stay in the territory of Russia.

The current stage of development of state migration policy is defined by the plethora of issues yet unworked out by law, particularly the issue of immigration status of foreign citizens and stateless persons as a subject of statutory regulation in a host country, including the stay of foreigners in the Russian Federation according to the purpose of their entry. People belonging to the category under consideration often break the law due to the lack of knowledge of rather complicated national legislation, primarily the migration regulations. Moreover, the fact of their poor awareness usually becomes the reason for the commission of abusive practices directed against these particular people.

Technically, migration processes are predictable to a great extent, because in the event of non-standard situations, conflicts, pandemics, such as COVID-19, etc., people massively rush to countries that are the most convenient in terms of migration, whatever people's real entry purpose is or regardless of whatever negative consequences expect them in case of breaching the law of a host state, primarily the migration one.

The paper is aimed at studying the problem of legal status (immigration status) of foreign residents in the Russian Federation. This problem is associated with a change in a

\footnotetext{
* Corresponding author: doptaganka@yandex.ru
} 
foreign citizen's purpose of entry into the territory of the host country. The fulfillment of this problem will positively affect the enforcement of foreign residents' rights, freedoms, legal interests in a host country and, as a result, the reputation of the Russian Federation in the world community.

\section{Materials and methods}

The present paper investigates the issues of changing the immigration status of foreign residents and stateless persons in different, mainly Western European countries. Having performed comparative legal analysis, the authors attempted to resolve these issues in terms of the Russian Federation, taking into account the incorporation of international law in the national legal framework.

The authors used a general scientific method of research - the dialectical method that shows the world's properties and relationships and objective laws of its development, as well as the method of comparative legal analysis. The paper examines the possibilities to extrapolate the positive European experience in solving the problem of changing the immigration status of citizens belonging to the considered category, and the activities of law enforcement agencies of Western Europe into the activities of the relevant Russian bodies of internal affairs in the field of migration.

To prepare the paper, the authors used national regulatory legal acts, Russian scientific publications of Russian researchers dealing with the migration issues and problems of foreign residents' stay in the territory of the Russian Federation and various foreign countries.

Issues of legal capacity implementation in the territory of the Russian Federation by foreign residents were analyzed by such scientists as S. A. Avakyan, A. S. Avtonomov, A.M. Arbuzkin, S.N. Baburin, M.V. Baglay, M.M. Boguslavsky, N.V. Vitruk, L.N. Galenskaya, N.N. Zinchenko, E.M. Koveshnikov, E.I. Kozlova, K.A. Corsic, O.E. Kutafin, E.A. Lukasheva, V.V. Maklakov, M.N. Marchenko, N.I. Matuzov, V.F. Mironova, T.M. Shamba, A.I. Ekimov and others.

\section{Results}

The Constitution of the Russian Federation gives equal rights to citizens of Russia, foreign citizens and stateless persons in the enforcement of fundamental rights and freedoms of a human and a citizen. Rights of a citizen are based on strong legal bonds connecting a person with a state. A citizen of a country has all the rights and freedoms in the territory of their state of citizenship, which, however, does not exclude the possibility of restricting them on the basis of law [1].

Such phrases from the Constitution as "everyone has the right", "everyone may", "everyone is guaranteed" mean that not only citizens of that country may reckon on state support and assistance in the implementation of rights and freedoms, but also foreign residents and stateless persons who legally reside in the territory of a host state.

While staying in the territory of any state, foreign citizens and stateless persons have a special legal status, and each person has their particular one. There are such legal statuses as a refugee, a migrant worker, an environmental migrant, etc. Legal status is a complicated umbrella legal category. Traditionally, a legal status of a person or a citizen is determined by a complex of such components as rights and freedoms, obligations, guarantees for the implementation of rights and obligations, the defense mechanism and responsibility. 
When considering the legal status of migrants, it would be convenient to divide them into external and internal migrants. The extent of legal status of migrants belonging to a particular type is to be determined with taking into account of the characteristics above.

Internal migrants moving around the territory of the Russian Federation are not limited in their rights and obligations.

External migrants are divided into emigrants and immigrants. Emigrants leave the territory of the Russian Federation and acquire rights and obligations of a host state along with restrictions imposed on a category of people, which these people belong to.

Immigrants (those people who arrive in the territory of the Russian Federation from other countries) enjoy equal rights and obligations along with citizens of Russia. This provision is enshrined in the Federal Law "On the Legal Status of Foreign Citizens in the Russian Federation" [2, 3, 4]. However, there are some exceptions to this principle of equality associated with meeting the requirements for protection of state or other secrets protected by law, implementation of public administration and other requirements.

For example, foreign citizens and stateless persons are limited in their political rights. These rights include the right to participate in state administration affairs, to elect or be elected to state administration bodies, to participate in the administration of justice, to be a civil servant, to participate in and to hold rallies, marches and demonstrations. They are not obliged to defend homeland, pay taxes, etc.

Personal rights are defined in the Constitution of the Russian Federation in accordance with the International Covenant on Civil and Political Rights, which states that "everyone has the right to liberty and security of person" (Article 9), "all persons shall be equal before the courts and tribunals", etc. Personal rights are defined and must be respected regardless of whether a person is or not a citizen of the state [1].

Differences in the scope of rights, freedoms, and obligations are defined through such concepts as "every person" and "every citizen". These concepts indicate differences in legal statuses of these categories of persons.

The Russian Federation, being a state governed by the rule of law at the categorical level, proclaims the value of rights and freedoms of a person, regardless of whether they have or do not have legal bonds with the state [5].

Today, there are more than 12 million migrants residing in the Russian Federation. Russia ranks the second after the United States of America in this parameter. The Main Directorate for Migration of the Ministry of Internal Affairs of Russia says that for the period January-March 2020, more than three million foreign citizens and stateless persons were passed the migration registration, approximately 500 thousand of work permits and licenses for conducting labor activity were issued to foreigners, as well as about 80 thousand of primary temporary residence permits [6].

The analysis of immigration flows, reasons for the foreigners' migration, their consolidation in the territory of the Russian Federation, suggests that migration has both positive and negative sides for our country.

The positive side of migration flows coming to our country is represented by the following facts:

Firstly, they contribute to the development of certain sectors of the country's economy, such as construction, agriculture, housing and utility services, trade.

Secondly, they provide an opportunity for the development of small and medium-sized businesses, being a significant and uncostly labor power.

Thirdly, they provide a solution to certain issues of population demography, increase the birth rate in Russia, etc.

The first and the most significant negative aspect of migration is the dumping of income level for the local population. 
The second one is the lack of potential for the increase in labor productivity, the decrease in qualifications of immigrant workers arriving in Russia.

The third is the growing economic polarization of the world $[7,8]$.

Fourth, the growing share of migrants who do not belong to the dominant ethnic group in some of economy sectors, which entails the depletion of the Russian-speaking population in those sectors.

Fifth, the extensive way of improving the demographic situation of our state, which means that it is not the birth rate in families whose members are the citizens Russia that is growing, it is the number of foreigners arriving, which makes the population grow.

To understand the impact of migration flows, develop mechanisms for influencing them, identify the causes and grounds for migration, and establish a migration balance, it is necessary to conduct scientific research, particularly from the standpoint of legal regulation.

Research and analysis of the legal status of foreign citizens and stateless persons in the Russian Federation is relevant due to the fact that it directly affects the rights and legal interests of Russian citizens, influences the social situation both in a particular region and in the whole state. Such researches have been updated in the last twenty years, which is associated with the increased migration flow to the Russian Federation. Of course, the main field of the scientific research is the study on legal status of migrants, on its elements, and above all, on legal capacity.

The main foreign citizens' and stateless persons' purposes for entering the territory of the Russian Federation is to study and resolve their work issues.

The authors agree with the opinion of A.A. Smolyakovykh, who speaks of the peculiarity of legal status of labor migrants in Russia and of the need to introduce the term "labor migrant" into legal terminology [9], and thereafter specify their legal status in the term "legal status of a "labor migrant".

This paper does not focus on the diversity of migrants, it perceives foreign citizens and stateless persons altogether and characterizes their legal status using a concept of "immigration status".

It should be noted that there is no consensus in legal science on the elemental content of immigration status. Some researchers say that the status of a foreign citizen or stateless person includes such elements as rights, freedoms, obligations [10, 11]. Others supplement it with citizenship, principles, legal personality (legal capacity and legal competency), guarantees, legal interests, etc. [12, 13].

Some scientists think that the structure of immigration status should include legal liability. Although it comes for non-fulfillment of obligations, which means that it does refer to all legal persons, but only to those who fail to comply with requirements of migration law.

Without entering the contest about the structure of this legal institution, it should be noted that all the plethora of viewpoints on this issue share such elements as rights, freedoms and obligations. The rest of elements describe the legal status of a foreigner in a host country and determine their most significant bonds with the state.

As noted above, legal relationship of a non-citizen with a host state largely stands out from citizen's relationship with their state. The first case implies that this relationship depends on a period during which a foreigner stays in the territory of a particular state. In addition, this relationship is not stable and permanent, since it can be interrupted at any moment by the request of any side [14]. Meanwhile a citizen's legal relationship with the state is permanent, it does not strengthen or weaken, it has the same stability regardless of whether the citizen is in the territory of their state or abroad.

It is noted in juridical literature that the main element of legal status of a person and a citizen is their legal capacity, which is a person's ability to enjoy their rights and fulfill 
obligations. Legal capacity depends on a person's age, education, physical and mental health.

The structures of a foreigner's migration legal capacity and a citizen's legal capacity are similar only at first glance. Their distinctive attributes are occasioned by specifics of both persons' legal bonds with a state. Specifics of a foreigner's legal bonds with a host state define the specifics of their legal competency, i.e. the ability to exercise rights through committing actions, fulfill the obligations stipulated by the migration legislation, and bear responsibility in accordance with this legislation.

Legal capacity of a foreign citizen or a stateless person is closely related to legal competency, which is also of a restrictive nature.

For example, Art. 32 of the Constitution of the Russian Federation does not allow foreign citizens to participate in public administration of the host state. Differences between a foreigner's and a citizen's rights, freedoms and obligations manifest themselves in their unequal scope $[1,15]$.

Foreign citizens being subjects of migration legal relations are obliged to comply with regulatory prohibitions and requirements of state authorities, local self-government and local officials. One of the obligations of a foreigner who permanently or temporarily resides in the Russian Federation is to annually inform the regional office of the internal affairs agency on migration issues about their staying in Russia. This procedure can be executed in person or via the Internet.

Migration of people is a constant process stemmed from various reasons. Migration is much more than a physical movement of people within a state or between states: it is a complex social process affecting certain political, economic and legal aspects of life of a society, a state, and a person [16].

Migration processes go on around the whole world. They are a part of the objective reality and one of the most important elements of the modern concept of migration security in any state.

Any foreigner arriving in the Russian Federation has a migration status. As it was mentioned above, this legal structure is a combination of such elements as the purpose of entry, rights, obligations, liabilities, guarantees, restrictions.

One of the problems associated with the implementation of legal status of foreign citizens is the need to change the purpose of entry into the territory of the Russian Federation for some objective reasons.

A foreign citizen defines their purpose of entry in a migration card when they actually cross the border. Thus, a foreigner is legalized in a host country [17]. However, the purpose of entry stated by a foreigner in their migration card may change during the period of their stay (residence). Marriage, job change or another circumstance may become such an objective reason for changing the purpose. In this case, according to the general rule enshrined in the legislation of the Russian Federation, a foreign citizen is obliged to leave the host country, enter it again and wright a new purpose in their migration card. Such an administrative-legal mechanism is obviously time- and cost-intensive for a foreign citizen, so it needs to be improved.

In this regard, it would be interesting to consider the experience of some Western European countries in changing the entry purpose of foreign citizens without a necessity to leave a host state.

For example, the Regulation of the European Parliament and the Council of the European Union [18, 19] having elaborated the Community Code on Visas, establishes general rules for issuing and extending Schengen visas, including their extension associated with a change in the entry purpose.

The authorized bodies of the member states of the European Union are capable of independently approving their own administrative regulations governing the procedure for 
changing the purpose of entry without leaving a host country. These administrative regulations slightly vary in different countries and regulate the ability to change a purpose of entry according to the main migration statuses validated in the European Union (for example, due to family reunion, admission to study, getting a job offer, etc.).

For example, in France, Sweden, Denmark and Spain, foreign citizens have the opportunity to apply for a change of an entry purpose (immigration status) online. In other member states of the European Union, an applicant is obliged to personally apply for the change in their entry purpose to a regional office of the authorized body.

The procedural time of processing such an application is set independently by an authorized body of a certain country, and usually ranges from 10 to 90 days, depending on a host country.

The main requirements applied to those persons who intend to change their purpose of entry (immigration status) are: the legality of staying in a host country; justification of a reason for changing the purpose of entry; proof of secure livelihood; proof of availability of place to reside; no criminal record certificate; payment of national duty, the amount of which is established depending on a host country (usually it equals 100 euros).

In the context of the issue considered in the paper, the experience of the USA is also of particular interest. Without going into details of a visa receiving procedure in the USA and the diversity of their visa types, it should be said that migration laws of different American states in most cases allow changing the purpose of entry (immigration status) without leaving the country. The administrative procedure aimed at resolving this issue implies that an applicant should personally appeal to a territorial office of the United States Citizenship and Immigration Services [20].

The procedural time of processing such an application is not unified, it depends on a state of residence of an applicant and may vary from a couple of months to six months.

The main demands placed on applicants intending to change the purpose of entry (immigration status) are: the legality of staying in the host country, the justification for changing a purpose of entry (immigration status), payment of the national duty amounting to $\$ 400$ (for submitting an application and taking biometric data) [14, 21].

Migration laws of Canada have similar requirements. Canada also allows changing one's immigration status without leaving the country. To apply, one should use the online service of the Department of Immigration, Refugees and Citizenship of Canada.

The procedural time for processing an application for changing the purpose of entry to Canada is usually 30 days or less. The basic requirements for applicants intending to change their purpose of entry (immigration status) are the legality of their staying in the host country; justification for changing the purpose of entry (immigration status), payment of the national duty in the amount of 100 Canadian dollars.

It should be noted that studies on the issue under consideration in France and Germany showed that legislative novelties on changing immigration status can make a positive contribution to the economy of a host state, as well as contribute to more efficient and smooth integration and adaptation of foreigners in these countries.

In the Russian Federation, the situation is a bit different. Foreign citizens may enter and leave the territory of the Russian Federation only with a visa issued in accordance with valid documents proving their identity and recognized by the Russian Federation in this capacity, unless otherwise provided by international treaties of the Russian Federation, as well as Federal Law No. 114-FZ "On the procedure for leaving the Russian Federation and entering the Russian Federation" or by decrees of the President of the Russian Federation. [22]

Depending on a purpose of a foreign citizen's or stateless person's entry into the Russian Federation and a purpose of their stay in the territory of Russia, a foreign citizen or 
a stateless person is issued a visa, the category of which can be diplomatic, official, regular or transit, as well as a temporary resident visa.

A visa is a permission issued by an authorized state body to enter the Russian Federation and stay in the Russian Federation or to transit through the territory of the Russian Federation according to a valid document proving the identity of a foreign citizen or stateless person and recognized by the Russian Federation in this capacity.

Visa shall contain the following information: surname and name of a foreign citizen or stateless person (written in letters of both the Russian and Latin alphabets), their date of birth, sex, citizenship (patriality), the number of an identification document of the denoted foreign citizen or stateless person that is recognized by the Russian Federation in this capacity, their photographic image (with the exception of a visa issued by federal executive authority in the field of internal affairs or its territorial office), date of visa issue, permitted term of residence in the territory of Russia for the denoted foreign citizen or stateless person, the number of invitation to enter the Russian Federation or the corresponding decision of a state body, the duration of their visa, the purpose of the trip of the denoted foreign citizen or stateless person, information about the inviting organization (or inviting natural person), number of entries granted by the visa.

The validity period of a visa is established in accordance with the Federal Law, unless otherwise provided by an international treaty of the Russian Federation. Depending on a number of allowed entries-leavings, visas can be single-entry, double-entry or multi-entry.

The actual purpose of entry of a foreign citizen and the purpose of their stay in the Russian Federation must correspond to the category of visa issued to them and the trip purpose indicated in it. The period of stay of a foreign citizen in the Russian Federation is determined by the validity period of the visa issued to them.

Foreign citizens who arrived in the Russian Federation on multiple business or multiple humanitarian one-year visas can stay in the Russian Federation for a total of not more than 90 days for each period of 180 days.

After the permitted period of stay expires, a foreigner is obliged to leave the territory of the Russian Federation.

It should be emphasized that regional bodies of the Ministry of Internal Affairs of Russia issue temporary resident visas, transit visas, multiple regular work visas for highly qualified specialists and visas permitting the entry into the Russian Federation with a purpose of obtaining Russian citizenship, extend visas' validity, annul and renew visas of all categories except diplomatic and business visas.

It is obvious that regional bodies of the Ministry of Internal Affairs of Russia issue visas to those foreign citizens who is already staying in the territory of the Russian Federation.

Today, the legality of foreign citizens' residing in the territory of the Russian Federation is defined in the compliance of an entry purpose specified in a migration card with an activity or work that is actually performed during the period of staying (residing) in the Russian Federation. For breaking the rules of entry into the Russian Federation or the regulations of staying (residence), which may inter alia manifest itself as inconsistency of a declared purpose of entry into the Russian Federation with a person's actual activity or occupation, a foreigner gets an administrative penalty in the form of administrative fine with or without further deportation from the Russian Federation.

Legal consequences of applying such a measure as deportation from the territory of the Russian Federation for a foreign citizen and a stateless person are highly unpleasant, and even traumatizing. The result for the considered category of citizens is a complete absence of legal grounds to enter into the territory of the Russian Federation during five years from the date of execution of the administrative penalty in the form of deportation.

Changing the entry purpose of a foreign citizen without leaving the Russian Federation is currently not provided for by national migration legislation. At the same time, the 
scientific community and people participating in various scientific forums are actively discussing this issue, studying world experience in changing the purpose of entry without leaving a host country.

In accordance with the main document of strategic development of the Russian Federation in the field of migration, the priority areas of the state migration policy in the field of improving legal, organizational and other mechanisms governing the entry of foreign citizens and stateless persons into the territory of the Russian state, their stay and/or residence, include ensuring the convenience and transparency of administrative procedures and the comprehensibility of criteria of entering the territory of Russia [6]. This list includes administrative procedures for issuing visas and providing the status of staying and/or residing in the territory of Russia with special emphasizing of their relevance and significance.

The fulfillment of this problem is boosted by digitalization of public administration manifesting itself in the development of telecommunication equipment and the Internet and elaboration of various online services. The use of such services significantly enhances the foreign citizens' abilities to exercise their rights more efficiently and cost-effectively, it helps them address the authorized governmental bodies of the Russian Federation, meanwhile helping those governmental bodies carry out related administrative procedures.

It is advisable to consider the international experience of applying the entry permission procedure, which is simplified by the use of electronic services, and the procedure of getting a visa via the Internet, without leaving home, which is especially relevant within periods of various epidemics or pandemics, such as COVID-19.

Positively assessing such experience, the Russian Federation is incorporating certain legal norms to the national legal migration system. Pilot projects have already been successfully tested in some constituent entities of the Russian Federation: in the Far Eastern Federal District, the Kaliningrad Region, Saint Petersburg and the Leningrad Region. It should be noted that since 2021, under the authority of Vladimir Putin, the President of the Russian Federation, a unified electronic single-entry visa will have been introduced throughout the whole territory of Russia.

Such a measure will positively affect the immigration status of foreign citizens and stateless persons, since it will provide them with legal entry into the territory of the Russian Federation for a period of up to 16 days for humanitarian or tourist purposes, as well as for the purpose of a guest visit.

Implementation of this measure requires additional amendments to be made to federal laws, primarily to the Federal Law "On the Legal Status of Foreign Citizens in the Russian Federation", as well as to other by-laws and regulatory acts.

It seems that implementation of this measure may result in the formation of a new governmental migration service, the code name of which would be: Change in the Purpose of Entry of Foreign Citizens and Stateless Persons During their Stay in the Russian Federation.

\section{Conclusion}

Improvement of the system of e-visas surely will contribute to the modernization of business relations between Russia and other countries, attracting financial investment flows in Russia. Moreover, many experts in the field of migration share the opinion that after introducing the system of electronic visas in Russia, the country will become the state with the most loyal visa policy among developed countries.

The issue under consideration obviously requires the improvement of the relevant administrative and legal regulation in a host state. In this regard, the foreign experience of countries mentioned above is of particular interest. 
However, there are several suggestions to be considered more thoroughly.

For example, it is crucial for the text of a statutory provision to contain the phase "legally staying in the territory of another state". It should be emphasized that the procedure for changing the purpose of entry, including both ways to provide this service: in person or via online services - should be entirely regulated at the national, and in case of Russia, at the federal level.

It is a labor or civil contract, not just a claim of an employer, that must be the basis for the legal opportunity to change the purpose of entry. This contract, in turn, will act as an additional burden for an employer and may have the effect that is opposite to the expected. In this regard, it is necessary to express concern that the indicated claim of the employer will not be a legally valid document that confirms the agreement on the employment of a foreign citizen.

The solution for this issue will definitely contribute to strengthening the image of the Russian Federation as a social, legal and democratic state that has ratified the International Treaties and constitutionally enshrined the priority of human and civil rights and freedoms in the territory of any state.

In addition, a positive solution to this problem will be a positive step in the successful implementation of the updated Concept of the State Migration Policy of the Russian Federation for 2019-2025, which was adopted in order to modernize the national migration statutory regulation.

Change of immigration status of a foreign citizen associated with a change in their purpose of entry into the territory of Russia, performed without leaving the country, will greatly facilitate the administrative procedure for consolidating the immigration status, and reduce time and cost expenditures of those people who legally stay in the country, as well as of employment-based immigrants arriving in the country.

The successful resolution of migrant-related issues depends on the development of effective instruments that would help regulate migration flows, fulfill the economic, social and political problems. Such changes may help Russia become a more welfare and democratic state.

\section{References}

1. The Constitution of the Russian Federation, adopted by a nationwide vote on December 12 (1993)

2. On the Legal Status of Foreign Citizens: Federal Law of July 25, 2002 No. 115-FZ (2019)

3. Code of the Russian Federation on Administrative Offenses of December 30, 2001 No. 195-FZ (current version), http://www.consultant.ru/

4. The Code of Administrative Procedure of the Russian Federation dated March 28, 2015 No. 21-FZ (current version), http://www.consultant.ru/

5. Y.A. Malyshev, Gosudarstvennoye upravleniye $v$ sfere vneshney trudovoy migratsii: teoriya i praktika. Monografiya (M., Yustitsinform, 2017)

6. On the procedure for leaving the Russian Federation and entering the Russian Federation: Federal Law of August 15, 1996 No. 114-FZ (current version), http://www.consultant.ru/.

7. On the migration card: Decree of the Government of the Russian Federation of August 16, 2004 No. 413 (2006) 
8. On approval of the Concept of state migration policy of the Russian Federation for 2019-2025: Decree of the President of the Russian Federation of 10.31.2018. No. 622, http://www.consultant.ru/

9. A.V. Stepanov, Tomsk State University Journal. Seriya Pravo 4(22) (2016)

10. I.Y. Lupenko, Migratsionnoye pravo 4 (2013)

11. N.A. Voronina, A.S. Zapesotskiy, V.A. Kartashkin, Prava cheloveka i pravovoye sotsial'noye gosudarstvo v Rossii (M., NORMA: INFRA-M, 2018)

12. P.N. Kobets, Konstitutsionnoye i munitsipal'noye pravo 1 (2004)

13. L.L. Rybakovskiy, Migratsiya naseleniya. Vyp. 5. Stadii migratsionnogo protsessa (2011)

14. M.L. Tyurkin, Gosudarstvo i pravo 9 (2004)

15. Regulation (EC) No. 810/2009 of the European Parliament and of the Council of 13 July 2009 establishing a Community Code on Visas (Visa Code), http://www.consultant.ru/

16. L.N. Anisimov, Trudovoye pravo 8 (2008)

17. Regulation (EC) No. 810/2009 of the European Parliament and of the Council of 13 July 2009 establishing a Community Code on Visas (Visa Code), http://www.consultant.ru

18. Synthesis Report of the European Migration Network "Changes in immigration status and purpose of stay: an overview of EU Member States approaches», http://mipas/lt

19. International Covenant on Civil and Political Rights (Adopted by the UN General Assembly resolution 2200A (XXI) at the 1496th plenary meeting of 16 December 1966)

20. R.R. Bitiyev, Osobennosti pravovogo statusa inostrantsev v Rossiyskoy Federatsii (M.: Moscow University for the Humanities, 2001)

21. A.A. Smol'yakov, Vestnik Sankt-Peterburgskogo universiteta 1(96) (2016)

22. Official web-site of the Ministry of Internal Affairs of the Russian Federation: mvd.ru 